\title{
First records of Geodia demosponges from the New England seamounts, an opportunity to test the use of DNA mini-barcodes on museum specimens
}

\author{
Paco Cárdenas ${ }^{1,2}$ (D) Jon A. Moore ${ }^{3}$
}

Received: 18 October 2016 / Revised: 18 May 2017 / Accepted: 31 July 2017 /Published online: 25 August 2017

(C) The Author(s) 2017. This article is an open access publication

\begin{abstract}
We report the first records of the sponge genus Geodia (Demospongiae, Tetractinellida, Geodiidae) from the New England Seamounts and Muir Seamount, at lower bathyal depths. Nine specimens collected between 2000 and 2005 belong to two boreal species (Geodia macandrewii and Geodia barretti) and a temperate species (Geodia megastrella). These records extend the distributions of these deep-sea amphi-Atlantic species to the west. Most of these specimens were originally fixed in formalin, which substantially degraded the DNA. We nonetheless managed to sequence two cytochrome $c$ oxidase subunit I (COI) minibarcodes: the universal mini-barcode at the $5^{\prime}$ end of the Folmer barcode (130 bp) and a newly proposed minibarcode at the $3^{\prime}$ end of the Folmer barcode (296 bp). These mini-barcodes unambiguously confirmed our identifications. As an additional test, we also successfully sequenced these two mini-barcodes from the holotype of G. barretti, collected in 1855 . We conclude by advocating the use of mini-barcodes on formalin-fixed or old specimens with degraded DNA.
\end{abstract}

Communicated by H. Stuckas

Paco Cárdenas

paco.cardenas@fkog.uu.se

1 Division of Pharmacognosy, Department of Medicinal Chemistry, BioMedical Center, Uppsala University, Husargatan 3, 751 23 Uppsala, Sweden

2 Department of Organismal Biology, Program in Systematic Biology, Evolutionary Biology Centre, Uppsala University, Norbyvägen 18D, 75236 Uppsala, Sweden

3 Wilkes Honors College, Florida Atlantic University, 5353 Parkside Dr., Jupiter, FL 33458, USA
Keywords Porifera $\cdot$ Geodia $\cdot$ Mini-barcodes $\cdot$ DNA barcoding $\cdot$ DNA degraded $\cdot$ Museum specimens

\section{Introduction}

The New England Seamounts (NES) are a 1,200-km-long chain of $\sim 35$ major volcanic peaks in the Northwest Atlantic, with elevations ranging from 400 to $4,000 \mathrm{~m}$ (Fig. 1). They extend from Georges Bank within the US Exclusive Economic Zone (EEZ) to the eastern end of the Bermuda Rise. Some $300 \mathrm{~km}$ east of the NES are the Corner Rise Seamounts, midway between the eastern end of the NES and the MidAtlantic Ridge. The NES are part of the New EnglandCorner Rise Seamount system, the result of a Cretaceous mantle-plume hotspot, which later gave rise to the Great Meteor group of seamounts south of the Azores (Tucholke and Smoot 1990; Sleep 1990). The Muir Seamount, which resides northeast of Bermuda is not part of this system, but it is a neighboring ancient volcano.

The first visual observations of the NES were made by camera drops in 1962 (Pratt and Thompson 1962) and the deep submersible vehicle (DSV) Alvin, on Bear Seamount in 1968 [Alvin dives 286 and 287, photos in Pratt (1968)] and on six other seamounts in 1974 (Nashville, Gilliss, Rehoboth, Manning, Balanus, and Mytilus), up to depths of 3,054 m (Houghton et al. 1977; Heirtzler et al. 1977). At that time, it was already clear that the most abundant benthic organisms were sponges (Demospongiae and Hexactinellida), especially on outcrops (Houghton et al. 1977). However, the fauna of the NES remained largely ignored until a series of Census of Seamounts (CENSEAM) campaigns in 2000-2005, part of the Census of Marine Life, began to collect and identify the fish and some invertebrates (Moore et al. 2003b, 2004). These campaigns clearly confirmed with video analysis that 
Fig. 1 Map showing the New England Seamounts where the Geodia specimens were collected. Previous Geodia records from the Flemish Cap and Grand Banks of Newfoundland (Cárdenas et al. 2013) are shown. The outer limits (200 nautical miles) of the Exclusive Economical Zone (EEZ) are represented by black lines. White, yellow and blue dots respectively represent records of Geodia macandrewii, Geodia barretti and Geodia megastrella. Map generated with GeoMapApp 3.5.0 (http://geomapapp.org)

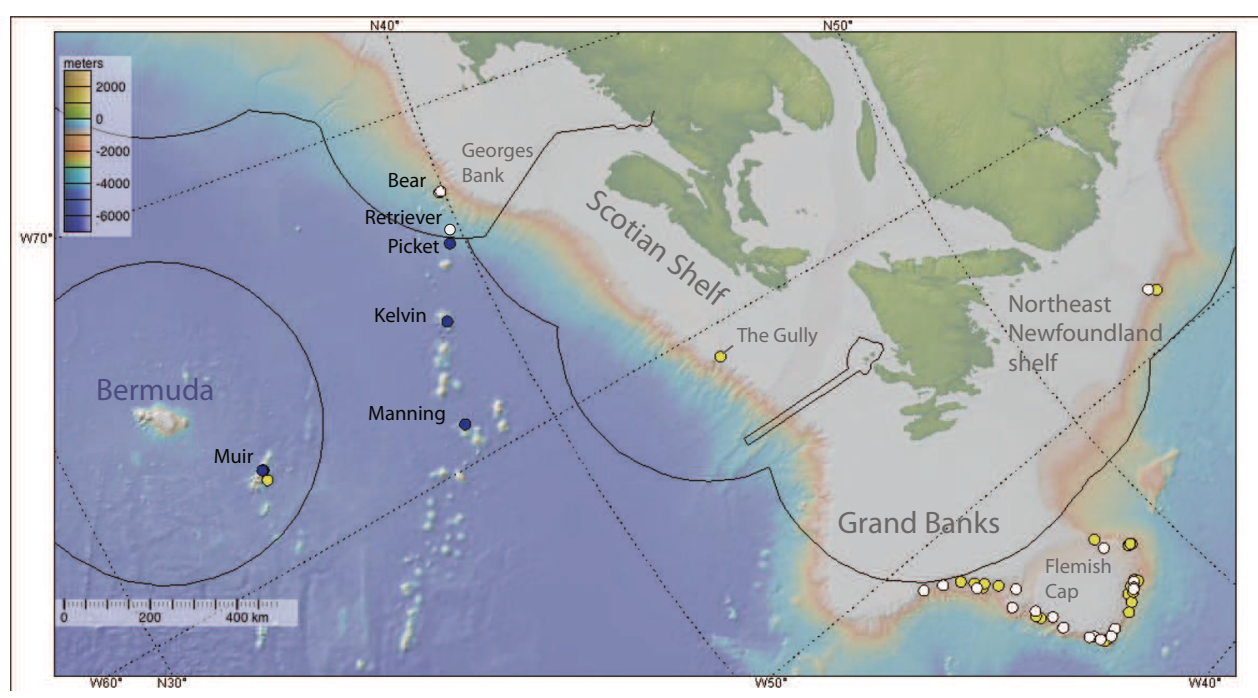

suspension feeders dominate these seamounts; the most abundant phyla in the NES were by far Porifera (sponges) at 54\%, followed by Cnidaria (mainly corals) at 23\% (Cho 2008). These studies also supported the idea that these seamounts represented biodiversity hotspots, which needed protection from deep-sea fishing. Thirteen seamounts from the NES and Corner Rise Seamounts were made Vulnerable Marine Ecosystem (VME) areas closed to fishing since 1 January 2007 (until 31 December 2020) and managed by the Northwest Atlantic Fisheries Organization (NAFO, http:// www.fao.org/fishery/vme/23646/en). Moreover, some of these seamounts (Bear, Physalia, Mytilus and Retriever) in the US EEZ (Fig. 1) are, since 15 September 2016, included in the first marine national monument in the Atlantic called the Northeast Canyons and Seamounts Marine National Monument, where fishing and mining is now prohibited (NOAA 2016).

The 2000-2005 campaigns led to the discovery of several new genera and new deep-sea octocoral species (Pante and Watling 2012; Watling and France 2011; Cairns 2007; Watling 2007; Simpson and Watling 2011) but regrettably, although some sponges were observed and collected during these cruises, they were never formally described. Therefore, the sponge fauna in the NES is unknown apart from four tentative identifications: Hexactinellida Farrea sp. and Rossellidae sp., the demosponges Geodia sp., and Cladorhizidae sp. (Moore et al. 2003b; Cho 2008). The closest formal sponge records (570-800 km away) are from the Challenger Expedition (1872-76), which dredged around the Bermuda islands some deep-sea temperate Tetractinellida demosponges-Geodia pachydermata Sollas, 1886 (st. 56: $1,966 \mathrm{~m}$ ), Stelletta tenuispicula Sollas, 1886 (station unknown) and Leiodermatium pfeifferae Carter, 1873 (st. 33: 795 m; st. 56) (Sollas 1888) - as well as deep-sea Hexactinellida - one species from station 33 and eight from station 56 (Schulze 1887). Otherwise, some 800-1,000 km northeast of the NES are many sponge records off Newfoundland, notably from the Grand Banks and Flemish Cap, where sponge abundance and diversity is high (Cárdenas et al. 2013; Murillo et al. 2012; Plotkin et al. 2017a, b).

To conclude, although sponges represent the most abundant benthic organisms in the NES area, sponge species composition is virtually unknown. And yet, this basic knowledge is absolutely necessary for the proper management, governance and conservation of these marine areas, especially for seamounts included in the VME and the US marine national monument. This knowledge is also required for a basic understanding of these remote ecosytems, and to assess the functional ecological role of sponges therein. This study will start to fill this knowledge gap by focusing on species of Geodia (Tetractinellida, Geodiidae). Indeed, Geodia is one of the few sponge morphotypes recorded during the CENSEAM campaigns, either after collection (Moore et al. 2003b) or on the videos from the RV Ronald H. Brown 2005 cruise to the NES and Corner Rise Seamount (Cho 2008, p. 47). One reason for that is that Geodia sponges are fairly noticeable deep-sea demosponges, with a typical massive subglobular or bowl shape, and a white to light brown color, usually clean of sediments (Fig. 2). Furthermore, they are sturdy sponges that can easily be collected without being too damaged in a trawl or with an articulated arm.

The main aim of this study was therefore to identify a collection of Geodia specimens collected during the CENSEAM campaigns. Thanks to the revision of North Atlantic Geodia (Cárdenas et al. 2013; Cárdenas and Rapp 2015; Cárdenas et al. 2010; Cárdenas et al. 2011), we have solid morphological and molecular knowledge to identify these specimens. Because of the degraded nature of the DNA in these specimens, this study was also an opportunity to test the use of mini-barcodes for sponge species identification. 
Fig. 2 Underwater pictures taken during the R/V Ronald H. Brown cruise RB04- 4 by ROV

Hercules; red lasers are $10 \mathrm{~cm}$ apart, like the bar scale. a Geodia megastrella and other sponges attached to a basalt boulder, Kelvin seamount, top of the plateau, $1,773 \mathrm{~m}, \sim 38^{\circ} 49.1981^{\prime}$ $\mathrm{N}, \sim 63^{\circ} 57.5414^{\prime} \mathrm{W}$ (coordinates 12 min after the photo), dive 9, 18 May 2004. b Geodia spp. and other sponges, Kelvin seamount, eastern peak of the seamount, $1,950 \mathrm{~m}, \sim 38^{\circ} 51.305^{\prime} \mathrm{N}, \sim 63^{\circ}$ $46.352^{\prime} \mathrm{W}$ (coordinates $48 \mathrm{~min}$ before photo), dive 11, 19 May 2004. c Geodia spp. Large bowl shaped Geodia with dirty hairy sides are probably

G. macandrewii. The other morphotypes are possibly G. megastrella or G. barretti. Retriever Seamount, 2,012 m, $\sim 39^{\circ} 48.4723, \sim 66^{\circ} 14.9982^{\prime} \mathrm{W}$ (30 min before photo), dive 13, 23 May 2004. Credit: Mountains in the Sea Research Group/NOAA

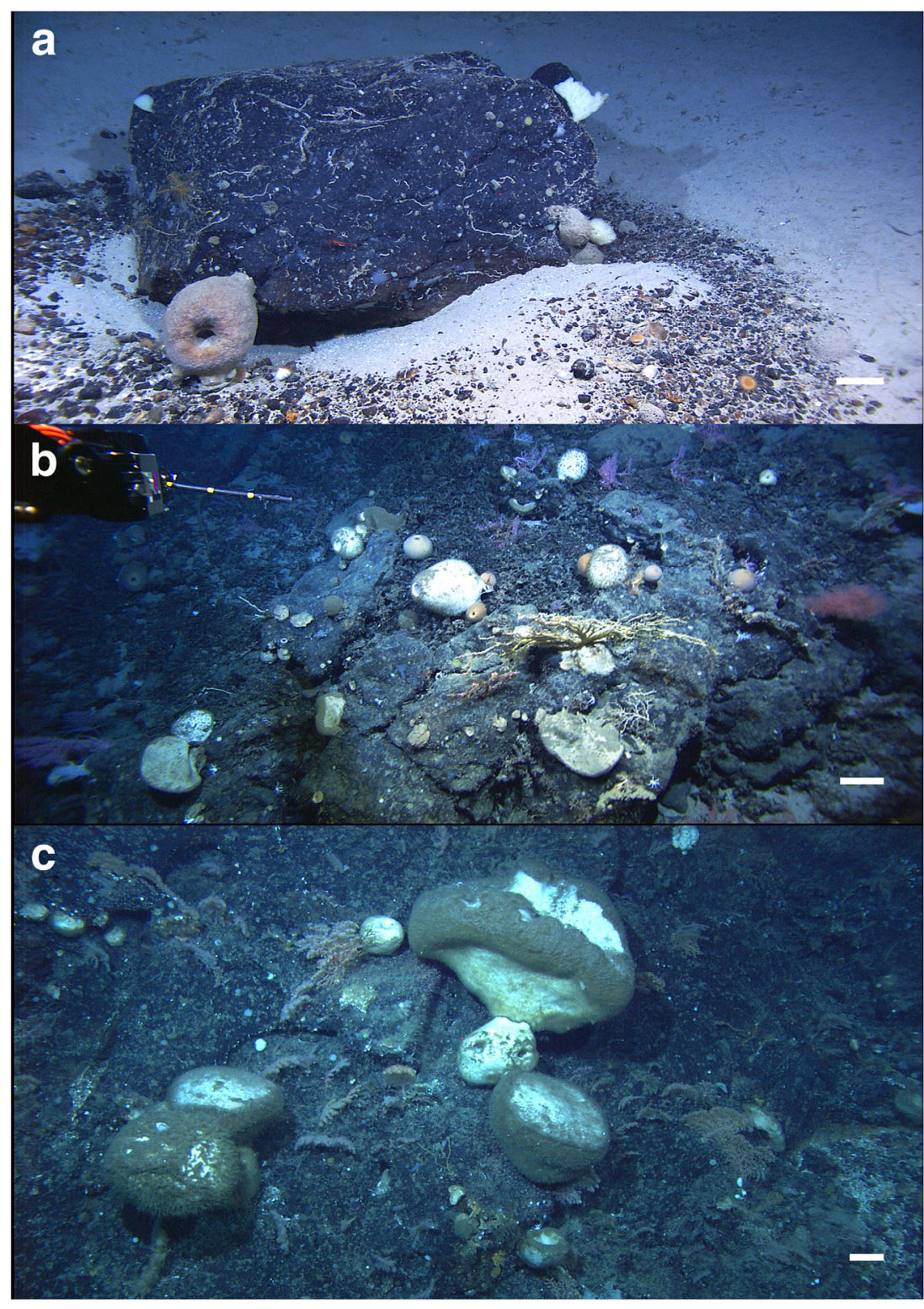

\section{Material and methods}

\section{Sponge sampling}

Specimens were collected during several NOAA New England Seamount campaigns that took place between 2000 and 2005: R/V Delaware II cruise DE00-11 (2000), $\mathrm{R} / \mathrm{V}$ Delaware II cruise DE02-06 (2002), R/V Atlantis cruise AT07-35 (2003), R/V Atlantis cruise AT08-01 (2003), R/V Ronald H. Brown cruise RB04-04 (2004) and R/V Atlantis cruise AT12-01 (2005). Details on the $\mathrm{R} / \mathrm{V}$ Delaware II cruises (2000-02) can be found in Moore et al. $(2003 \mathrm{~b}, 2004)$. Details of the other NOAA expeditions (2003-05) are available from the NOAA Ocean Explorer website (http://oceanexplorer.noaa.gov/ explorations/explorations.html). Specimens were collected with a Yankee 36 bottom trawl (2000-02), with the DSV Alvin (2003-05) or with the remote operated vehicle (ROV) Hercules in the lower bathyal at depths between 1,489 and 2,829 $\mathrm{m}$ depth.

Pictures of the specimens were made on deck. Most specimens were bulk fixed in formalin before being transferred to $70 \%$ ethanol for long-term storage at room temperature. YPM 27001 is the only specimen to have been frozen on board $\left(-20{ }^{\circ} \mathrm{C}\right.$ freezer) and later fixed in $70 \%$ ethanol at the Peabody Museum of Natural History (YPM), Yale University, New Haven, USA. When these samples were sent to Uppsala University to be studied, they were sent in Carosafe ${ }^{\circledR}$ (a formaldehyde-free holding solution), and then stored back in ethanol before morphological and molecular studies. Today, these specimens are stored at the YPM at room temperature. 


\section{Molecular studies}

DNA was extracted using the DNeasy® Blood and Tissue kit (Qiagen, Hilden, Germany) in accordance with the manufacturer's instructions. Sponge pieces were taken from the choanosome and lysed for $2 \mathrm{~h}$ in ATL buffer (Qiagen) with proteinase $\mathrm{K}$. Extracted DNA was diluted and stored in $50 \mu \mathrm{l}$ or $100 \mu \mathrm{l} \mathrm{AE}$ buffer (Qiagen) at $-4{ }^{\circ} \mathrm{C}$. Polymerase chain reactions (PCRs) were made in $25 \mu \mathrm{l}$ solutions using PuReTaqTM Ready-To-Go ${ }^{\text {TM }}$ PCR beads (GE Healthcare, Little Chalfont, UK). We tried to sequence the barcoding COI Folmer fragment (659 bp) on a Touchgene Gradient thermocycler (Techne, Cambridge, UK), using primers LCO1490 and HCO2198 (Folmer et al. 1994), the PCR program: $\left[5 \mathrm{~min} / 94{ }^{\circ} \mathrm{C} ; 37\right.$ cycles $\left(15 \mathrm{~s} / 94{ }^{\circ} \mathrm{C}, 15 \mathrm{~s} / 46{ }^{\circ} \mathrm{C}, 15 \mathrm{~s} /\right.$ $\left.72{ }^{\circ} \mathrm{C}\right) ; 7 \mathrm{~min} / 72{ }^{\circ} \mathrm{C}$ ] and negative/positive controls. Although, the $\mathrm{LCO} / \mathrm{HCO}$ primer pair is known to work on Geodia species (Cárdenas et al. 2010, 2011), our attempts were unsuccessful for all specimens except for YPM 27001.

To assess the quality and quantity of the DNA extractions, we first ran $1 \mu \mathrm{l}$ of the extracted DNA on a $1.5 \%$ agarose gel. As expected from specimens fixed in formalin (Zimmermann et al. 2008, and references within), we observed smearing indicating degraded DNA, with highest intensity in the range of 100-500 bp. This range of sequences has been shown to be semi-stable in museum specimens (Zimmermann et al. 2008). The least degraded DNA came from YPM 027001, which had been frozen on board before being fixed in $70 \%$ ethanol. Further analyses on the Agilent 2200 TapeStation (Agilent Technologies, Santa Clara, CA, USA) with the High Sensitivity D1000 ScreenTape (Agilent Technologies) confirmed that several samples had very low DNA concentrations $(22.1 \mathrm{pg} / \mu \mathrm{l}$ and lower), and sometimes too low to be detected.

Hajibabaei et al. (2006) developed the idea of sequencing a mini-barcode for such cases of museum specimens with degraded DNA. It has been shown that one can still amplify smaller sequences from degraded DNA and for this purpose, Meusnier et al. (2008) designed primers Uni-minibarF1 $(\sim \mathrm{LCO})$ and Uni-minibarR1 to amplify a universal minibarcode for animals, which corresponds to the first $130 \mathrm{bp}$ of the Folmer fragment. Mini-barcodes have never been used in sponges. From the large Tetractinellida COI dataset from Kelly and Cárdenas (2016) opened in the alignment freeware AliView v.1.18 (Larsson 2014), we designed the degenerated primer Tetract-minibarR1 (5'-RAARAYCATTATAA GRCCRTGRGC-3') with the exact same position and length as Uni-minibarR1 but more specific to the Tetractinellida. We then used the primer pair LCO/Tetract-minibarR1 and $2 \mu$ of DNA template to amplify a 179-bp sequence (130 bp without primers), using the same thermocycler and PCR program described above.

According to a sub-alignment of only Geodia Folmer sequences, the universal mini-barcode would not be variable enough to discriminate the different species belonging to the Depressiogeodia clade (G. barretti, G. hentscheli and G. megastrella) (Cárdenas et al. 2011), so we also targeted a longer mini-barcode at the $3^{\prime}$ end of the Folmer fragment, which showed interspecific variation in this clade. For this purpose, we designed the new primer DepressioCOI393F (5'-GCCTCTATCGAGCGTTCAGG-3'); position 393 stands for the primer position in the COI of Amphimedon queenslandica Hooper and van Soest, 2006. We then used the primer pair DepressioCOI393F/HCO to amplify a 342bp sequence (296 bp without primers), using the same thermocycler and PCR program described above. This minibarcode will be called Depressio-minibarcode henceforth.

To test the use of universal mini-barcode and the Depression-minibarcode on old museum material, we also extracted the DNA from the dry holotype of Geodia barretti (NHM 1877.5.21.1399) collected on 6 August 1855 on the Western coast of Norway by Robert McAndrew and Lucas Barrett (McAndrew 1856; Bowerbank 1872). It is unclear how this specimen was preserved but it seems it was dried after collection (Bowerbank 1872; p. 198). The DNA extract was diluted in only $15 \mu \mathrm{l} \mathrm{AE}$ buffer since we anticipated its low concentration. Its concentration was measured using the Qubit ${ }^{\circledR}$ dsDNA BR Assay Kit (Invitrogen, Waltham, MA, USA) with a quantification range of 2-1,000 ng: the spectrophotometer could not detect any DNA in our extract. We nonetheless ran PCRs following the same protocol described above.

All PCR products were purified using the ExoSAP-IT® kit (USB Europe, Staufen, Germany) and sent for sequencing (Macrogen Europe, Amsterdam, The Netherlands) using the same primers as in the PCRs. Sequences were assembled and blasted using Geneious ${ }^{\circledR} 8.1$ (created by Biomatters, http:// www.geneious.com). When we had two COI mini-barcodes from the same specimen, we merged these sequences into a single one using the 'merge' option in AliView. Merged sequences $(130+296=426$ characters $)$ were submitted to Genbank (KX982850-KX982854).

\section{Morphological studies}

After digesting a piece of sponge tissue in chlorine, and washing the remaining spicules successively with water, $50 \%$ ethanol and $100 \%$ ethanol, spicules mounts were made using Eukitt $^{\mathrm{TM}}$ mounting medium (Sigma-Aldich, St Louis, MO, USA). Twenty-five spicules per spicule type were measured, unless otherwise stated using a light microscope and an eyepiece micrometer. Observations of the pores were made with a stereomicroscope.

The following abbreviations are used for institutions mentioned in the text: BNHM, The Natural History Museum, London, UK; MNHN, Muséum national d'Histoire naturelle, Paris, France; ZMA, Zoological Museum in Amsterdam, 
The Netherlands (collection now moved to Naturalis, Leiden); ZMBN, Bergen Museum, Bergen, Norway; ZMUC, The Zoological Museum, Copenhagen, Denmark.

\section{Taxonomy and results}

We identified a total of three species of Geodia, all new records for this area: G. macandrewii (Bear Seamount), G. barretti (Muir Seamount) and G. megastrella (Picket, Kelvin, Manning and Muir Seamounts). Their distributions are shown in Fig. 1. We succeeded in sequencing the two mini-barcodes for all three species, including the 161-yearold holotype of $G$. barretti. Morphological and molecular studies were concordant. Collecting information and identifications results are available in the PANGAEA data repository (doi:10.1594/PANGAEA.867276).

\section{Class DEMOSPONGIAE Sollas, 1885}

Subclass HETEROSCLEROMORPHA Cárdenas et al., 2012

Order TETRACTINELLIDA Marshall, 1876

Suborder ASTROPHORINA Sollas, 1887

Family GEODIIDAE Gray, 1867

Genus Geodia Lamarck, 1815

Geodia macandrewii Bowerbank, 1858

\section{Material}

YPM 28261, Bear Seamount, $39^{\circ} 53^{\prime} \mathrm{N}, 67^{\circ} 26^{\prime} \mathrm{W}$ to $39^{\circ} 52^{\prime} \mathrm{N}$, $67^{\circ} 23^{\prime} \mathrm{W}$, Yankee 36 otter trawl, net depth: 1,489 m, R/V Delaware II cruise DE02-06, st. 46, coll. J. A. Moore, 29 July 2002 (preservation not recorded, not likely formalin).

YPM 27001, Bear Seamount, $39^{\circ} 55.22^{\prime} \mathrm{N}, 67^{\circ} 28.83^{\prime} \mathrm{W}$ to $39^{\circ} 54.24^{\prime} \mathrm{N}, 67^{\circ} 29.80^{\prime} \mathrm{W}$, Yankee 36 otter trawl (1-h trawl), 1,826-2,008 m, R/V Delaware II cruise DE00-11, st. 17, coll. J. A. Moore, 5 December 2000 (frozen on board, then fixed in $70 \%$ ethanol).

Outer morphology (Figs. 2c, 3)

YPM 27001 is a large bowl-shaped specimen, $40 \mathrm{~cm}$ in diameter, with a flattened top surface (Fig. 3a). YPM 28261 is smaller with a more inflated top surface (Fig. $3 b)$. Cribriporal pores $(0.5-1 \mathrm{~mm}$ in diameter) are on the sides, cribriporal to uniporal oscules on the top surface $(0.5-1 \mathrm{~mm}$ in diameter); cortex is $1-2 \mathrm{~mm}$ (YPM 27001) or 1-1.5 mm (YPM 28261) thick. Cortex is white; the choanosome is also white, a bit creamer. YPM 28261 has parasitic Hyrrokkin sp. foraminifera (Fig. 3c) deeply settled in the cortex, only in the pore areas (Fig. 3b) (identification on pictures by $\mathrm{T}$. Cedhagen, Aarhus University, Denmark).

Spicules, YPM 28261

Megascleres:

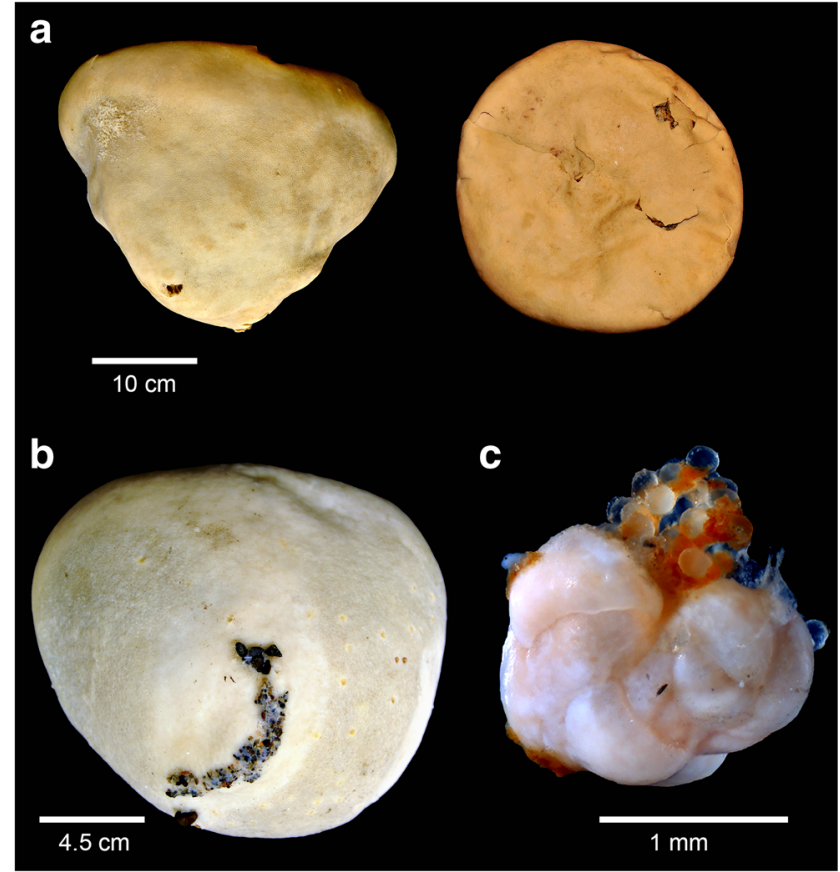

Fig. 3 Geodia macandrewii Bowerbank, 1858. a YPM 27001, Bear Seamount, 1,489 m, side view (left) and top view (right). b YPM 28261, Bear Seamount, 1,826-2,008 m, side view. Notice the small holes made by the foraminifera Hyrrokkin sp. c Close-up of one Hyrrokkin sp. All pictures by E. A. Lazo-Wasem (YPM)

(a) Oxeas I: length, 4,025 $\mu \mathrm{m}(n=1)$; width, $25 \mu \mathrm{m}$ $(n=1)$. (b) Oxeas II (= microxeas): mostly straight but sometimes slightly bent; length, 262-318.8-360 $\mu \mathrm{m}$; width, 7.59.3-11 $\mu \mathrm{m}$. (c) Orthotriaenes: rhabdome length, 2,8256,642-7,920 $\mu \mathrm{m}(n=10)$; width, 40-106-120 $\mu \mathrm{m}(n=15)$; clad length, 230-690-1,000 $\mu \mathrm{m}(n=10)$. (d) Anatriaenes: rhabdome length, >15 mm; width, 40-40.6-42 $\mu \mathrm{m}(n=3)$; clad length, $260 \mu \mathrm{m}(n=1)$. (e) Promesotriaene: rhabdome width, $11 \mu \mathrm{m}(n=1)$; clad length, $260 \mu \mathrm{m}(n=1)$; central clad length, $200 \mu \mathrm{m}(n=1)$.

Microscleres:

(f) Sterrasters (Fig. 4a): spherical to slightly elongated;

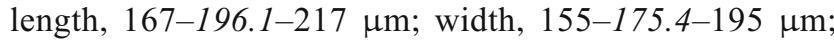
thickness, 122-150 $\mu \mathrm{m}$. (g) Spheroxyasters: rough, 7.5-11$15 \mu \mathrm{m}$ in diameter. (h) Oxyasters: rough; diameter, 17-19.6$25 \mu \mathrm{m}$

\section{COI barcoding and mini-barcoding}

We managed to sequence the universal Folmer barcoding fragment for YPM 27001 (Genbank no. KX982850), it is $100 \%$ identical to all other $G$. macandrewii sequenced previously (e.g., EU4422198) (Cárdenas et al. 2011, 2013): nine sequences from Norway (four), Spitsbergen (two), Porcupine Bank (one), Davis Strait (one) and Flemish Cap (one). The universal mini-barcode sequence of YPM 28261 was $100 \%$ 
Fig. 4 Sterrasters and oxyasters of Geodia spp. observed with a light microscope. a

G. macandrewii, YPM 28261. b

G. megastrella, YPM 28870. c

G. megastrella, YPM 34730. d

G. barretti, YPM 28886. All

pictures are at the same scale as shown in a

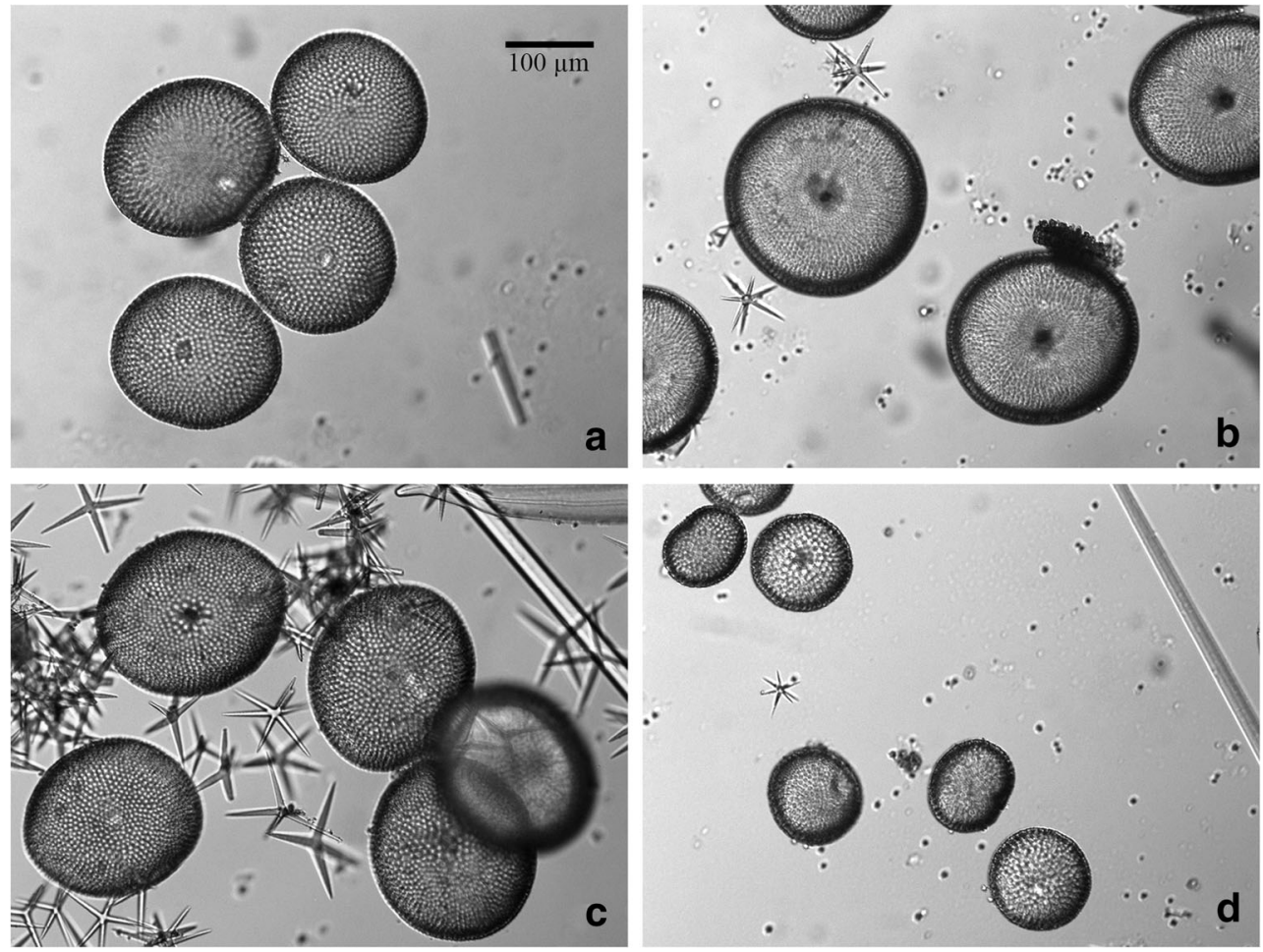

identical to the first $130 \mathrm{bp}$ of the Folmer fragment of G. macandrewii, this was the first blast hit.

\section{Bathymetric range}

157-2,012 m (Cárdenas et al. 2013; this study).

\section{Remarks}

With its moderately thick cortex (1-2 $\mathrm{mm})$, its very hairy sides and cribriporal pores and oscules, these specimens look like typical G. macandrewii. Furthermore, spicule measurements are perfectly in accordance with the description of the species (Cárdenas and Rapp 2015; Cárdenas et al. 2013). G. macandrewii was only collected in the Bear Seamount (seamount closest to the continental shelf, Fig. 1) but underwater pictures suggest it is also present in the Retriever Seamount (Fig. 2c), $\sim 100 \mathrm{~km}$ from Bear Seamount (Fig. 1). Both of these seamounts are now protected as part of the Northeast Canyons and Seamounts Marine National Monument. Sightings in the Retriever Seamount were at 2,012 $\mathrm{m}$ depth, making it the deepest record for this species. The foraminifera could be the common parasitic Hyrrokkin sarcophaga Cedhagen 1994 described in the Northeast Atlantic on Geodia sponges, including G. macandrewii (Beuck et al. 2008; Cedhagen 1994) but genetic data are wanting to confirm this identification.

Geodia megastrella Carter, 1876

\section{Material}

YPM 28870, Muir Seamount, $33^{\circ} 46.54^{\prime} \mathrm{N}, 62^{\circ} 34.29^{\prime} \mathrm{W}$, DSV Alvin dive 3885, st. 1, 2,027 m, R/V Atlantis cruise AT07-35, coll. D. Scheirer and R. Waller, 3 June 2003 (fixed in formalin).

YPM 28891, Muir Seamount, $33^{\circ} 45.20^{\prime} \mathrm{N}, 62^{\circ} 45.10^{\prime} \mathrm{W}$, DSV Alvin dive 3887 , st. 5, 2,265 m, R/V Atlantis cruise AT07-35, coll. J. Adkins and L. Robinson, 6 June 2003 (fixed in formalin).

YPM 58540, Muir Seamount, $33^{\circ} 45.20^{\prime} \mathrm{N}, 62^{\circ} 45.10^{\prime} \mathrm{W}$, DSV Alvin dive 3887 , st. 5, 2,265 m, R/V Atlantis cruise AT07-35, coll. J. Adkins and L. Robinson, 6 June 2003 (fixed in formalin).

YPM 34730, Kelvin Seamount, $38^{\circ} 50.992^{\prime} \mathrm{N}, 63^{\circ} 55.572^{\prime}$ W, DSV Alvin dive 3904, st. 208-1, 1,880 m, R/V Atlantis cruise AT08-01, coll. S. C. France and I. G. Babb, 16 July 2003 (fixed in formalin).

YPM 36027, Manning Seamount, $38^{\circ} 08.09^{\prime} \mathrm{N}, 61^{\circ} 06.965^{\prime}$ W, ROV Hercules dive 6, St. MAN708, 1,718 m, R/V Ronald H. Brown cruise RB04-04, coll. J. A. Moore, 15 May 2004 (preservation not recorded).

YPM 46869, Picket Seamount, 39³9.14052'N, $65^{\circ} 56.600400^{\prime} \mathrm{W}$, DSV Alvin dive 4162, st. PIC 104-1, $1,995 \mathrm{~m}, \mathrm{R} / \mathrm{V}$ Atlantis cruise AT12-01, coll. L. Mullineaux and S. Eltgroth, 28 October 2005 (fixed in formalin).

Outer morphology (Figs. 2a, 5)

YPM 28870, 46869, 34730 and 58540 are large subspherical specimens. Diameters range from $8 \mathrm{~cm}$ (YPM 


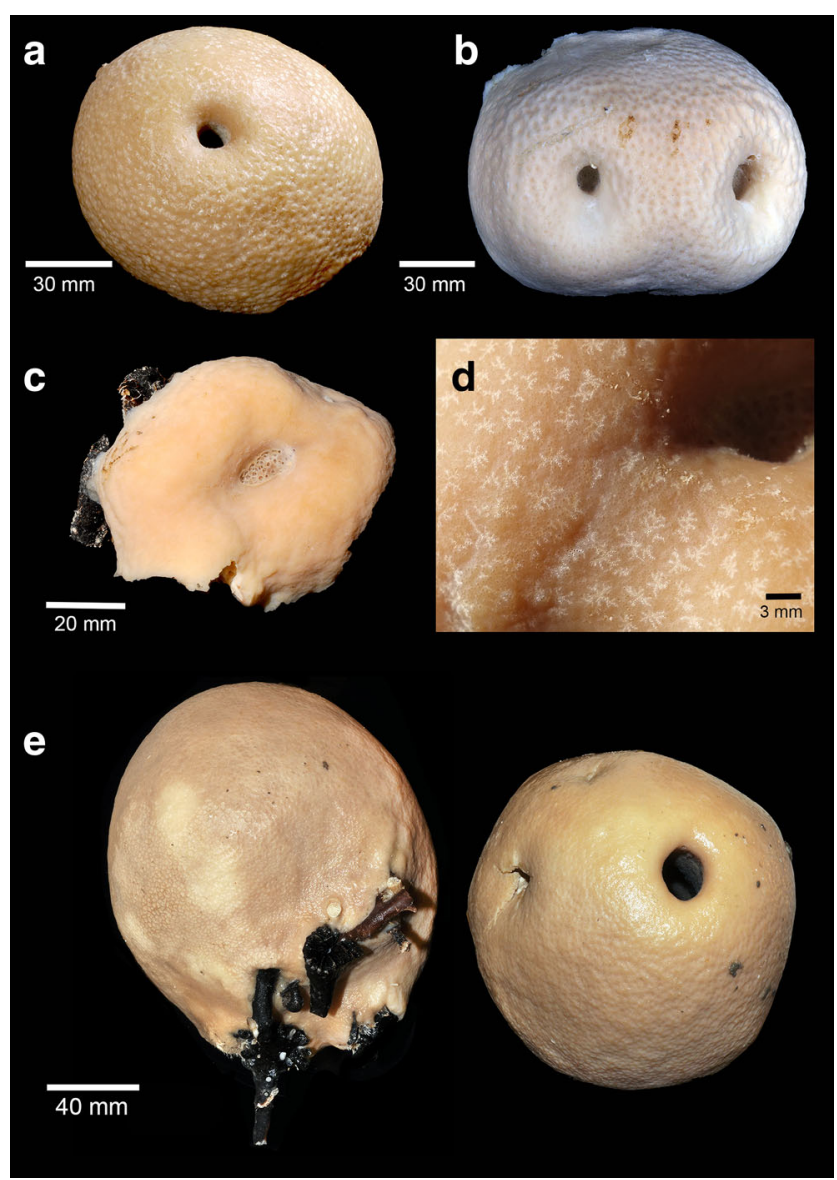

Fig. 5 Geodia megastrella Carter, 1876. a YPM 28870, Muir Seamount, 2,027 m. b YPM 34730, Kelvin Seamount, 1,880 m. c YPM 28891, Muir Seamount, 2,265 m. d Close-up on the pores of YPM 28891. e YPM 58540, Muir Seamount, 2,265 m. All pictures by E. A. Lazo-Wasem (YPM), except d

$46869)$ to $20 \mathrm{~cm}$ (YPM 58540). YPM 28891 is more flattened $(6 \times 5 \mathrm{~cm})$. All samples have one single preoscule opening (0.3-1.5 $\mathrm{cm}$ in diameter) on the top surface except for YPM 34730 that has two (Fig. 5b). Smaller preoscule openings (3$4 \mathrm{~mm}$ ) have raised margins (YPM 36027). On the sides, cribriporal areas $(2-3 \mathrm{~mm}$ in diameter) have characteristic 'snowflake' shapes (Fig. 5d). Specimens are not compressible with a very hard and thick cortex $(1.5-3 \mathrm{~mm})$. Surface is smooth, to human-skin-like, to beehive-like patterns. YPM 28891 and 58540 are growing on coral rubble; YPM 36027 is growing on dead Lophelia skeleton, while YPM 46869 was attached to the base of live Paragorgia. External color alive and in ethanol is brown to light brown. Internal color alive and in ethanol is cream (lighter than cortex).

Spicules, YPM 28870, unless stated otherwise.

Megascleres:

(a) Oxeas I: straight or slightly bent, some are slightly centrotylote; length, 2,600-2,998-3,680 $\mu \mathrm{m}(n=7)$; width, 35-46.8-60 $\mu \mathrm{m}(n=7)$. (b) Oxeas II (= microxeas): straight or slightly bent, with very sharp tips; length, 225-
372.4-570 $\mu \mathrm{m}$; width, 3.5-6.8-7.5 $\mu \mathrm{m}$. (c) Orthotriaenes: rhabdome length, 3,160-3,480 $\mu \mathrm{m}(n=2)$; width, 90-97$110 \mu \mathrm{m}(n=10)$.

Microscleres:

(d) Sterrasters: spherical to subspherical (Fig. 4b), 195212.6-225 $\mu \mathrm{m}$ in diameter; thickness, 155-160 $\mu \mathrm{m}$; sterrasters in the rest of the specimens are more elongated (sometimes lemon-shaped) (Fig. 4c). (e) Strongylasters: 5.0 7.2-10 $\mu \mathrm{m}$ in diameter. (f) Oxyasters I: 5-9 rough actines; diameter, 73-90.5-105 $\mu \mathrm{m}$ (Fig. 4b-c); oxyasters in YPM 34730, 28891 and 36027 have many oxyasters reduced to 3-2 actines, which often makes much larger oxyasters (diameter, $60-121.3-187 \mu \mathrm{m}$ in YPM 34730) with actines up to $90 \mu \mathrm{m}$ long. (g) Oxyasters II: thin rough actines; diameter, $15-29.4-50 \mu \mathrm{m}$. Anatriaenes and protriaenes not observed.

\section{COI mini-barcoding}

Identical universal mini-barcodes (130 bp) were obtained for three samples (out of six): YPM 028891, YPM 046869 and YPM 034730. Identical Depressio-minibarcodes (296 bp) were obtained for two samples: YPM 028891, YPM 046869. These Depressio-minibarcodes are 100\% identical with a $G$. megastrella sequence from the Gulf of Cadiz (ZMAPOR 21231, Genbank no. HM592741) but have 1-bp difference with two other $G$. megastrella sequences from Scotland and Irving Seamount (south of the Azores) (Cárdenas et al. 2011). Two merged mini-barcode sequences (YPM 028891, 046869) were submitted to Genbank (KX982851-KX982852).

\section{Bathymetric range}

200-2,600 m (Cárdenas and Rapp 2015; Topsent 1911).

\section{Remarks}

Spicule measurements and external morphology are perfectly in accordance with previous descriptions from the MidAtlantic Ridge and Madeira (Cárdenas and Rapp 2015; Topsent 1928). Lemon-shaped sterrasters have also been observed in MNHN-DT1298 from Madeira, $2380 \mathrm{~m}$ (Topsent 1928). Contrary to its sister species in the Depressiogeodia clade (the boreal G. barretti and the arctic G. hentscheli) (Cárdenas et al. 2011), this species is not known to form mass occurrences (i.e., sponge grounds). This species was sighted (Fig. 2a) and collected between 1,719 and 2,265 m depth on several NES (Picket, Kelvin and Manning) and Muir Seamount (Fig. 1). Although the Depressio-minibarcodes are identical to the COI sequence of $G$. megastrella ZMAPOR 21231, the external morphology and spicule sizes of the latter are slightly different from our specimens (and those from the Mid-Atlantic Ridge or Madeira), thus suggesting the presence 
of genetically cryptic species with identical COI in this already suspected species complex (Cárdenas et al. 2011). This is the first time that this typical deep-sea northeastern Atlantic Geodia is recorded on the northwestern side. This G. megastrella morphotype (identical to the specimens from Madeira and the Mid-Atlantic Ridge) can therefore be added to the growing list of deep-sea amphi-Atlantic boreo/arctic/temperate demosponges (Cárdenas et al. 2013; Cárdenas and Rapp 2015).

Geodia barretti Bowerbank, 1858

\section{Material}

YPM 28886, Muir Seamount, 334․ ${ }^{\circ}{ }^{\prime} \mathrm{N}, 62^{\circ} 36.06^{\prime} \mathrm{W}$, DSV Alvin dive 3886, st. 1, 2,829 m, R/V Atlantis cruise AT07-35, coll. T. Shank and S. Eltgroth, 5 June 2003 (preservation not recorded, probably formalin).

Outer morphology (Fig. 6)

Spherical, $6 \mathrm{~cm}$ in diameter, regular short hispidity, slightly compressible, light-brown external color, cream color inside (lighter), one elevated preoscule (3.5 $\mathrm{mm}$ in diameter), slightly flexible cortex $=1 \mathrm{~mm}$, radial skeleton organization, Pores areas $<1 \mathrm{~mm}$, on the bottom half of the sphere. Dichotriaenes/pro(meso)triaenes/anatriaenes crossing the surface.

\section{Spicules, YPM 28886}

Megascleres:

(a) Oxeas I: slightly bent, some are slightly centrotylote; length, 860-2,328-3,680 $\mu \mathrm{m}(n=12)$; width, 16-34.9-50 $\mu \mathrm{m}$ $(n=10)$. (b) Oxeas II (= microxeas): straight or slightly bent; length, 262-470.2-600 $\mu \mathrm{m}$; width, 5-7.6-17 $\mu \mathrm{m}$. (c) Dichotriaenes: rhabdome length, 2,520-2,768-3,000 $\mu \mathrm{m}$ $(n=12)$; width, 110-126-140 $\mu \mathrm{m}(n=11)$; protoclad length, 200-243-300 $\mu \mathrm{m}(n=15)$; deuteroclad length, 200-284$360 \mu \mathrm{m}(n=15)$. (d) Anatriaenes: only observed at the surface, not measured. (e) Mesotriaenes: clads are sickle shaped; rhabdome length, 1,475 $\mu \mathrm{m}(n=1)$; width, 5-12.3-17 $\mu \mathrm{m}$ $(n=3)$; clad length, 170-253-300 $\mu \mathrm{m}(n=3)$; central clad length, 20-50-70 $\mu \mathrm{m}$.

Microscleres (Fig. 4d):

Fig. 6 Geodia barretti Bowerbank, 1858, YPM 28886, Muir Seamount, 2,829 m. a Deck picture of specimen. $\mathbf{b}$ Deck picture of specimen broken in half (during collecting by the manipulator arm). Pictures by $\mathrm{J}$. A. Moore (f) Sterrasters: spherical; 85-114.5-125 $\mu \mathrm{m}$ in diameter; thickness, 95-97 $\mu \mathrm{m}$. (g) Strongylasters: 5-6.4-10 $\mu \mathrm{m}$ in diameter. (h) Oxyasters I: rough actines, a few have a single much longer actine (up to $72 \mu \mathrm{m}$ long); diameter, 38-47.7$65 \mu \mathrm{m}$. (i) Oxyasters II: thin actines; diameter, 12.5-24.9$38 \mu \mathrm{m}$.

\section{COI mini-barcoding}

The universal mini-barcode and Depressio-minibarcode were both sequenced. The resulting merged sequence (Genbank no. KX982853) was $100 \%$ identical to the COI haplotype 1 of G. barretti (e.g., EU442195).

\section{Bathymetric range}

30-2,829 m (Cárdenas and Rapp 2013; this study)

\section{Remarks}

Spicule measurements are in accordance with the description of the species (Cárdenas et al. 2013). A few differences are, however, noted. This specimen has the largest sterrasters (85114.5-125 $\mu \mathrm{m}$ ) measured to date for this species. Since there seems to be a relation between depth and size of sterrasters (Cárdenas and Rapp 2013), this may be related to the fact that this is the deepest record of G. barretti. Also, unlike previous observations in $G$. barretti, there is no clear size distinction between oxyasters I and II in this specimen; it is more of a continuum. Moreover, the large oxyasters with a single unusually long actine found here had never been observed in G. barretti before, or even in North Atlantic Geodia species. Finally, the relatively dark brown color and the hispidity of this specimen are also atypical for this species (Cárdenas et al. 2013). All these small differences suggest that the Muir Seamount may somehow represent a separate population. This is the western-most record of this species in the Atlantic and although no specimens were collected in the NES, its presence on the Muir Seamount suggests its presence in the neighboring NES. The carnivorous sponge
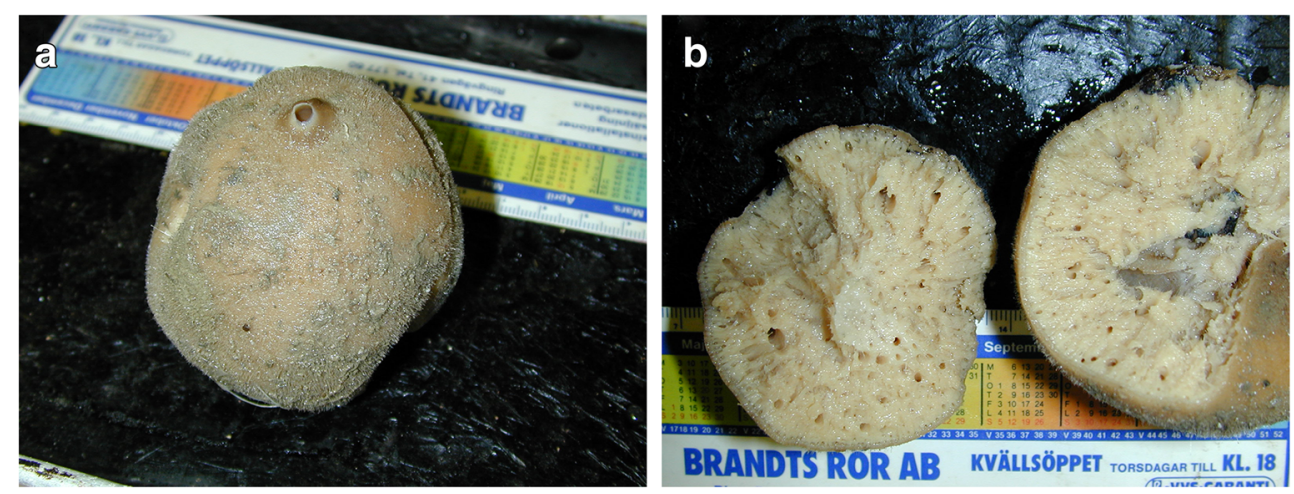
Abyssocladia polycephalus Hestetun et al. 2016 was found growing on this specimen.

To test the use of the two mini-barcodes on old type material, we tried to get mini-barcodes from the dry holotype of Geodia barretti (NHM 1877.5.21.1399) collected in 1855. Although DNA could not be detected in our extract, we succeeded in sequencing the COI universal mini-barcodes and the Depressio-minibarcodes (following the PCR protocols detailed above), thus obtaining a total of $416 \mathrm{bp}$ from this 161 year-old type. The merged sequence, submitted to the Sponge Barcoding Project (SBP no. 1647, Genbank no. KX982854), was $100 \%$ identical to the COI haplotype 1 of G. barretti.

\section{Discussion}

\section{Biogeography}

We report here the first records of G. macandrewii, G. barretti and G. megastrella in the NES area. The modeling of the distribution of boreo-arctic Geodia species by Howell et al. (2016) failed to predict the presence of boreal Geodia in the NES, which is probably an indication of the knowledge gaps pertaining to the distribution of deep-sea sponges. Geodia spp. seem highly abundant in this region with 698 sightings in the NES and 140 in the Corner Rise Seamounts (Cho 2008, p. 47). No large sponge grounds such as the ones observed off Newfoundland (Murillo et al. 2012) have been recorded from the NES so far, despite the presence of key boreal sponge ground species (G. barretti or G. macandrewii). Aggregations of different Geodia species are present (Fig. $2 b, c)$ but their extent and density has not been measured.

This small collection suggests that the NES and Muir Seamount Geodia fauna include both boreal (G. barretti and G. macandrewii) and temperate species (G. megastrella). The mix of boreal and temperate species in the NES has been noticed for other groups such as fish (Moore et al. 2003b, 2003a; Quattrini et al. 2015), cephalopods (Shea et al. 2017) and octocorals (Cairns 2007; Quattrini et al. 2015; Watling et al. 2011). Moore et al. (2003b, 2003a) found that there is an area of overlap between the boreal fauna and temperate fauna along the slope of Georges Bank. The Deep Western Boundary Current (DWBC) along the continental slope of Georges Bank originates from the cold Labrador Current and actually runs at depths down to Cape Hatteras (Spall 1996; Moore et al. 2004). Other boreal/temperate Geodia species live in sympatry with $G$. barretti and G. macandrewii in the Flemish Cap/Grand Banks area: the boreal Geodia atlantica (Stephens, 1915), Geodia phlegraei (Sollas, 1880) and the temperate Geodia nodastrella Carter, 1876 (Cárdenas and Rapp 2015; Cárdenas et al. 2013). Therefore, we can expect to find these other species in the NES, should their ecological needs (species interactions, ecological conditions) be met there. Furthermore, the warm-core eddies off the Gulf Stream drop tropical species into the area. As a result, Bear Seamount's fish and cephalopod fauna has a mix of boreal, temperate and tropical species (Moore et al. 2003a; Shea et al. 2017). Although pelagic animals are obviously very mobile and require different ecological interactions/conditions than sponges, this opens up the possibility of also finding subtropical Geodia species in the NES. For instance, the type locality of the temperate/subtropical Geodia pachydermata is nearby (in the Bermuda, $250 \mathrm{~km}$ from Muir Seamount), so we could expect this species to be present in this area. These results also highlight the overlap between the biogeographic lower bathyal provinces BY2 (Northern Atlantic Boreal, including the Grand Banks and Flemish Cap) and BY4 (North Atlantic, including the NES) (Watling et al. 2013) in this region.

Although our specimen of G. barretti from Muir Seamount presented small morphological differences with typical specimens, G. macandrewii and G. megastrella specimens were quite typical of the species. This collection is however too small to deduce anything about local endemism on seamounts. Genetic studies on other benthic animals (octocorals and antipatharians) from the NES and Corner Seamounts suggest that populations from the individual seamounts are not isolated (Thoma et al. 2009) so it may be similar for sponges.

\section{Mini-barcodes}

With a full-length barcode (= Folmer barcode) the three species from this study could potentially be identified unambiguously (Cárdenas et al. 2011). However, because of the degraded DNA, obtaining a full-length barcode was only possible for the only specimen originally frozen on board: YPM 27001 (G. macandrewii). Sequencing of the universal minibarcode (= first $130 \mathrm{bp}$ of the Folmer barcode) was easier (five sequences obtained out of eight specimens) and succeeded in identifying unambiguously G. macandrewii but not G. barretti and G. megastrella. The latter two species have identical universal mini-barcodes, as do all Geodia species that belong to the Depressiogeodia clade (G. barretti, G. hentscheli and G. megastrella sensu lato).

Although restricted to a few species, our results therefore show that, as expected, identification of sponges is not as accurate with the COI universal mini-barcodes as with the COI full-length barcode. Knowing that sponge COI barcoding is already limited due to its slow evolution (Schuster et al. 2017, and references within) up to the point that it cannot discriminate close species (Addis and Peterson 2005; Cárdenas and Rapp 2012; Carella et al. 2016), the minibarcode worsens the problem. And yet, in our small study, the universal mini-barcode unambiguously identified the Geodia genus, which could already be of tremendous help for taxonomists, ecologists and other end-users of sponge 
barcoding. In some cases, we show that it can even identify to the species level (G. macandrewii).

The Depressio-minibarcode (= last 296 bp of the Folmer barcode) performed as well as the full-length barcode since it could by itself identify unambiguously each of these Geodia species. It was actually variable enough to also discriminate the different G. megastrella and G. barretti haplotypes. Future work should determine if these results-Depressiominibarcode was more variable than the universal minibarcode - can be confirmed for other sponges. The primer Tetract-minibarR 1 is positioned in a moderately conserved part of COI, with no known mitochondrial intron insertion sites (Schuster et al. 2017). We show here that the primer pair LCO/Tetract-minibarR1 worked for Geodia species, but it should work for all Tetractinellida: we have already successfully tested it on several tetractinellid genera (Vulcanella, Pachastrella, Rhabdastrella, Ecionemia, Erylus, Caminus, Stelletta, Antarctotetilla, Cinachyrella, Tetilla and Craniella). Primer Depressio398F is specific to the Depressiogeodia clade but it appears to work occasionally on other Geodia species (data not shown).

One important advantage of COI mini-barcodes is that they do not require yet another sponge barcoding database, which would take years to build; they take advantage of the already substantial COI sponge barcode database in Genbank and the Sponge Barcoding Project (http://www.palaeontologie.geo. uni-muenchen.de/SBP). More generally, one major benefit with mini-barcodes is that one can barcode specimens with degraded DNA, such as the ones from this study. We managed to get sequences of 100-300 bp from formalin-fixed specimens collected 11-14 years ago. This opens the possibility to use numerous outstanding museum collections, for which the sponge specimens have unfortunately been in formalin (e.g., MAR-Eco 2004 collection, ZMBN; BIOFAR 19881990 collection, ZMUC) or simply bulk-fixed in $70 \%$ ethanol (this is the case for many recent collections at the MNHN). It has been previously suggested that, in Vertebrates at least, tissue lysis is the main obstacle in obtaining DNA from formaldehyde-exposed tissues due to the DNA crosslinking to the surrounding tissue, making complete lysis difficult (Zimmermann et al. 2008). In our case, we did not observe any problem to completely dissolve the formalin-fixed sponge pieces in our lysis buffer. However, the amounts of DNA we extracted using a standard kit were indeed extremely low (usually $<25 \mathrm{pg} / \mu \mathrm{l})$.

Mini-barcodes would also be strong assets to easily sequence old museum material, especially type material (Hajibabaei et al. 2006; Hajibabaei and McKenna 2012). In this study, we succeeded in obtaining the two mini-barcodes from the 161-year-old dry holotype of Geodia barretti (NHM 1877.5.21.1399), collected in 1855. According to the World Porifera Database (van Soest et al. 2017), 44\% of all sponge species (accepted and unaccepted) were described during the eighteenth and nineteenth centuries; another $47 \%$ of all species were described in the twentieth century. This means that $91 \%$ of all sponge species have type material that predate the year 2000, a time when sponge molecular phylogenetics was just emerging and sponge taxonomists seldom thought of properly preserving the DNA of their specimens. Consequently, this means that $91 \%$ of sponge types probably have degraded DNA. Even though it seems possible to sequence full-length barcodes even for century-old types (Erpenbeck et al. 2015), this is rather the exception than the rule. On the other hand, we foresee that obtaining COI and 28S mini-barcodes from reference specimens will certainly be easier and therefore more common, which would drastically raise the level of confidence users will have in the sponge barcoding database. Additionally, these mini-barcodes may solve a plethora of phylogenetic and taxonomical questions (e.g., Erpenbeck et al. 2015). Furthermore, if one is not satisfied with the short universal mini-barcode, its sequence is a prerequisite to try to get the full-length barcode, by primer walking for instance.

Acknowledgments Many thanks to Eric A. Lazo-Wasem (senior collections manager, Yale Peabody Museum of Natural History) for sharing this material, for his diligent efforts to answer our queries and for taking pictures of the specimens. The collection of specimens was made possible by generous funding provided by the NOAA Ocean Exploration program (NA03OAR4600116), NOAA National Marine Fisheries Service (for ship time on RV Delaware II), NOAA National Undersea Research Program (NA05OAR4301001), and NSF (OCE-0096373). We would like to thank J. Moore's colleagues in the Mountains in the Sea and Deep Atlantic Stepping Stones Research Groups: J. Adkins, P. Auster, S. France, I. Babb, L. Mullineaux, K. Scanlon, T. Shank, M. Vecchione, and L. Watling and for their help in securing the necessary funding and ship time to allow us to explore north-western Atlantic seamounts. Our sincere thanks to the captains and crew of the RV Atlantis and the NOAA ships Delaware II and Ronald H. Brown, who together with the skillful pilots of the DSV Alvin and ROV Hercules, made it possible to collect high quality imagery and specimens from great depths. We thank Cécile Jolly (EBC, Uppsala University) for assistance using the 2200 TapeStation and Raphaël Cárdenas (Gluntens Montessoriskola, Uppsala) for help measuring the specimens. This work has received funding from an Inez Johansson grant (HT2014, Uppsala University, Sweden) and the European Union's Horizon 2020 research and innovation program through the SponGES project (grant agreement no. 679849).

Open Access This article is distributed under the terms of the Creative Commons Attribution 4.0 International License (http:// creativecommons.org/licenses/by/4.0/), which permits unrestricted use, distribution, and reproduction in any medium, provided you give appropriate credit to the original author(s) and the source, provide a link to the Creative Commons license, and indicate if changes were made.

\section{References}

Addis JS, Peterson KJ (2005) Phylogenetic relationships of freshwater sponges (Porifera, Spongillina) inferred from analyses of $18 \mathrm{~S}$ rDNA, COI mt DNA, and ITS2 rDNA sequences. Zool Scr 34(6): 549-557. doi:10.1111/j.1463-6409.2005.00211.x 
Beuck L, Correa ML, Freiwald A, Wisshak M, Tapanila L (2008) Biogeographical distribution of Hyrrokkin (Rosalinidae, foraminifera) and its host-specific morphological and textural trace variability. In: Wisshak M, Tapanila L (eds) Current developments in bioerosion. Erlangen Earth Conference Series. Springer, Berlin Heidelberg, pp 329-360

Bowerbank JS (1858) On the anatomy and physiology of the Spongiadae. Part I. On the Spicula. Philos Trans R Soc Lond 148(2):279-332 pls XXII-XXVI

Bowerbank JS (1872) Contributions to a general history of the Spongiadae. Part II. Proc Zool Soc Lond 1872:196-202 pls X-XI

Cairns SD (2007) Studies on western Atlantic Octocorallia (Gorgonacea: Primnoidae). Part 8: new records of Primnoidae from the New England and corner rise seamounts. Proc Biol Soc Wash 120 (3):243263. doi:10.2988/0006-324X (2007)120[243:SOWAOG]2.0.CO;2

Cárdenas P, Rapp HT (2012) A review of Norwegian streptaster-bearing Astrophorida (Porifera: Demospongiae: Tetractinellida), new records and a new species. Zootaxa 3253:1-53

Cárdenas P, Rapp HT (2013) Disrupted spiculogenesis in deep-water Geodiidae (Porifera, Demospongiae) growing in shallow waters. Invertebr Biol 132(3):173-194

Cárdenas P, Rapp HT (2015) Demosponges from the northern midAtlantic ridge shed more light on the diversity and biogeography of North Atlantic deep-sea sponges. J Mar Biol Assoc UK 95(7): 1475-1516. doi:10.1017/S0025315415000983

Cárdenas P, Rapp HT, Schander C, Tendal OS (2010) Molecular taxonomy and phylogeny of the Geodiidae (Porifera, Demospongiae, Astrophorida) - combining phylogenetic and Linnaean classification. Zool Scr 39(1):89-106. doi:10.1111/j.1463-6409.2009.00402.x

Cárdenas P, Xavier JR, Reveillaud J, Schander C, Rapp HT (2011) Molecular phylogeny of the Astrophorida (Porifera, Demospongiae) reveals an unexpected high level of spicule homoplasy. PLoS One 6(4):e18318

Cárdenas P, Pérez T, Boury-Esnault N (2012) Sponge systematics facing new challenges. Adv Mar Biol 61:79-209

Cárdenas P, Rapp HT, Klitgaard AB, Best M, Thollesson M, Tendal OS (2013) Taxonomy, biogeography and DNA barcodes of Geodia species (Porifera, Demospongiae, Tetractinellida) in the Atlantic boreoarctic region. Zool J Linnean Soc 169:251-311

Carella M, Agell G, Cárdenas P, Uriz MJ (2016) Phylogenetic reassessment of Antarctic Tetillidae (Demospongiae, Tetractinellida) reveals new genera and genetic similarity among morphologically distinct species. PLoS One 11(8):e0160718. doi:10.1371/journal.pone.0160718

Carter HJ (1876) Descriptions and figures of deep-sea sponges and their spicules, from the Atlantic Ocean, dredged up on board H.M.S.'porcupine', chiefly in 1869 (concluded). Ann Mag Nat Hist 4(18):(105):226-240; (106):307-324; (107):388-410; (108): 458-479, pls XII-XVI

Cedhagen T (1994) Taxonomy and biology of Hyrrokin sarcophaga gen. Et sp. n., a parasitic foraminiferan (Rosalinidae). Sarsia 79:65-82

Cho WW (2008) Faunal biogeography, community structure, and genetic connectivity of North Atlantic seamounts, available at http://hdl. Handle.Net/1721.1/45312. PhD dissertation, MIT/WHOI, Massachusetts Institute of Technology, Cambridge

Erpenbeck D, Ekins M, Enghuber N, Hooper JNA, Lehnert H, Poliseno A, Schuster A, Setiawan E, De Voogd NJ, Wörheide G, Van Soest RWM (2015) Nothing in (sponge) biology makes sense - except when based on holotypes. J Mar Biol Assoc UK 96(2):305-311. doi: $10.1017 / \mathrm{S} 0025315415000521$

Folmer O, Black M, Hoeh W, Lutz R, Vrijenhoek R (1994) DNA primers for amplification of mitochondrial cytochrome c oxidase subunit I from diverse metazoan invertebrates. Mol Mar Biol Biotechnol 3(5): 294-299

Gray JE (1867) Notes on the arrangement of sponges, with the descriptions of some new genera. Proc Zool Soc Lond 2:492-558, pls XXVII-XXVIII
Hajibabaei M, McKenna C (2012) DNA Minibarcodes. In: Kress JW, Erickson LD (eds) DNA Barcodes: methods and protocols. Humana Press, Totowa, pp 339-353. doi: 10.1007/978-1-61779591-6_15

Hajibabaei M, Smith MA, Janzen DH, Rodriguez JJ, Whitfield JB, Hebert PDN (2006) A minimalist barcode can identify a specimen whose DNA is degraded. Mol Ecol Notes 6(4):959-964. doi: 10. $1111 / j .1471-8286.2006 .01470 . x$

Heirtzler JR, Taylor PT, Ballard RD, Houghton RL (1977) The 1974 Alvin dives on corner rise and New England seamounts. WHOI technical report vol WHOI-77-08, Woods Hole, 59 pp.

Hestetun JT, Pomponi SA, Rapp HT (2016) The cladorhizid fauna (Porifera, Poecilosclerida) of the Caribbean and adjacent waters. Zootaxa 4175(6):521-538

Hooper JNA, van Soest RWM (2006) A new species of Amphimedon (Porifera, Demospongiae, Haplosclerida, Niphatidae) from the Capricorn-bunker Group of Islands, great barrier reef, Australia: target species for the 'sponge genome project'. Zootaxa 1314:31-39

Houghton RL, Heirtzler JR, Ballard RD, Taylor PT (1977) Submersible observations of the New England seamounts. Naturwissenschaften 64(7):348-355. doi:10.1007/bf00368733

Howell K-L, Piechaud N, Downie A-L, Kenny A (2016) The distribution of deep-sea sponge aggregations in the North Atlantic and implications for their effective spatial management. Deep-Sea Res I Oceanogr Res Pap 115:309-320. doi:10.1016/j.dsr.2016.07.005

Kelly M, Cárdenas P (2016) An unprecedented new genus and family of Tetractinellida (Porifera, Demospongiae) from New Zealand's Colville ridge, with a new type of mitochondrial group I intron. Zool J Linnean Soc 177(2):335-352. doi:10.1111/zoj.12365

Lamarck JBP (1815) Suite des polypiers empâtés, vol 1. Mémoires du Muséum d'Histoire Naturelle, Paris, pp 69-80 162-168, 331-340

Larsson A (2014) Ali view: a fast and lightweight alignment viewer and editor for large datasets. Bioinformatics 30(22):3276-3278. doi:10. 1093/bioinformatics/btu531

Marshall W (1876) Ideen über die Verwandtschaftscverhältnisse der Hexactinelliden. Z Wiss Zool 27(1):113-136

McAndrew R (1856) Notes on a dredging excursion to the North Cape. Proceedings of the Literary and Philosophical Society of Liverpool 1(10):51-66

Meusnier I, Singer GAC, Landry J-F, Hickey DA, Hebert PDN, Hajibabaei M (2008) A universal DNA mini-barcode for biodiversity analysis. BMC Genomics 9(214). doi: 10.1186/1471-2164-9-214

Moore JA, Hartel KE, Craddock JE, Galbraith JK (2003a) An annotated list of deepwater fishes from off the New England region, with new area records. Northeast Nat 10(2):159-248

Moore JA, Vecchione M, Hartel KE, Collette BB, Galbraith JK, Gibbons R, Turnipseed M, Southworth M, Watkins E (2003b) Biodiversity of bear seamount, New England seamount chain: results of exploratory trawling. J Northwest Atl Fish Sci 31:363-372

Moore JA, Vecchione M, Collette BB, Gibbons R, Hartel KE (2004) Selected fauna of bear seamount (New England seamount chain) and the presence of "natural invader" species. Arch Fish Mar Res 51(1-3):217-226

Murillo FJ, Muñoz PD, Cristobo J, Ríos P, González C, Kenchington E, Serrano A (2012) Deep-sea sponge grounds of the Flemish cap, Flemish pass and the grand banks of Newfoundland (Northwest Atlantic Ocean): distribution and species composition. Mar Biol Res 8(9):842-854

NOAA (2016) First marine national monument created in Atlantic. Sept. 19, 2016. http://www.noaa.gov/news/first-marine-nationalmonument-created-in-atlantic

Pante E, Watling L (2012) Chrysogorgia from the New England and corner seamounts: Atlantic-Pacific connections. J Mar Biol Assoc UK 92(05):911-927. doi:10.1017/S0025315411001354

Plotkin A, Voigt O, Willassen E, Rapp HT (2017a) Molecular phylogenies challenge the classification of Polymastiidae (Porifera, 
Demospongiae) based on morphology. Org Divers Evol 17(1):4566. doi: 10.1007/s13127-016-0301-7

Plotkin A, Gerasimova E, Rapp HT (2017b) Polymastiidae (Porifera: Demospongiae) of the Nordic and Siberian seas. J Mar Biol Assoc UK:1-63. doi: 10.1017/S0025315417000285

Pratt RM (1968) Photography of seamounts. In: Hersey JB (ed) Deep-sea photography. Johns Hopkins Press, Baltimore, pp 145-158

Pratt RM, Thompson SL (1962) Report on Atlantis cruises \#280-281, June-July 1962. WHOI technical report, vol WHOI-62-40, Woods Hole, $18 \mathrm{pp}$

Quattrini AM, Nizinski MS, Chaytor JD, Demopoulos AWJ, Roark EB, France SC, Moore JA, Heyl T, Auster PJ, Kinlan B, Ruppel C, Elliott KP, Kennedy BRC, Lobecker E, Skarke A, Shank TM (2015) Exploration of the canyon-incised continental margin of the northeastern United States reveals dynamic habitats and diverse communities. PLoS One 10(10):e0139904. doi:10.1371/journal. pone.0139904

Schulze FE (1887) Report on the Hexactinellida collected by H.M.S. 'Challenger' during the years 1873-1876. Report on the scientific results of the voyage of H.M.S. 'Challenger', 1873-1876. Zoology 21:1-514

Schuster A, Lopez JV, Becking LE, Kelly M, Pomponi SA, Wörheide G, Erpenbeck D, Cárdenas P (2017) Evolution of group I introns in Porifera: new evidence for intron mobility and implications for DNA barcoding. BMC Evol Biol 17:82. doi:10.1186/s12862-0170928-9

Shea EK, Judkins H, Staudinger MD, Dimkovikj VH, Lindgren A, Vecchione M (2017) Cephalopod biodiversity in the vicinity of Bear seamount, western North Atlantic based on exploratory trawling from 2000 to 2014. Mar Biodivers 1-24. doi: 10.1007/ s12526-017-0633-3

Simpson A, Watling L (2011) Precious corals (Coralliidae) from northwestern Atlantic seamounts. J Mar Biol Assoc UK 91(2):369-382. doi:10.1017/S002531541000086X

Sleep NH (1990) Monteregian hotspot track: a long-lived mantle plume. J Geophys Res-Sol Ea 95(B13):21983-21990. doi:10.1029/ JB095iB13p21983

Sollas WJ (1880) The sponge-fauna of Norway; a report on the Rev. A.M. Norman's collection of sponges from the Norwegian coast. Ann Mag Nat Hist 5(5(29)):396-409 pl. XVII

Sollas WJ (1885) A classification of the sponges. Ann Mag Nat Hist $5(16): 395$

Sollas WJ (1887) Sponges. In: Black A, Black C (eds) Encyclopaedia Britannica, 9th edn, vol 22. A \& C Black, Edinburgh, pp 412-429

Sollas WJ (1888) Report on the Tetractinellida collected by H.M.S. challenger, during the years 1873-1876. Report on the scientific results of the voyage of H.M.S. challenger, 1873-1876. Zoology 25(63):1458 pls I-XLIV

Spall MA (1996) Dynamics of the Gulf Stream/deep western boundary current crossover. Part II: low-frequency internal oscillations. J Phys Oceanogr 26(10):2169-2182. doi:10.1175/1520-0485 (1996) 026<2169:DOTGSW >2.0.CO;2

Stephens J (1915) Sponges of the Coasts of Ireland. I.-The Triaxonia and part of the Tetraxonida. Fisheries, Ireland Scientific Investigations 1914 (4):1-43, pls I-V

Thoma JN, Pante E, Brugler MR, France SC (2009) Deep-sea octocorals and antipatharians show no evidence of seamount-scale endemism in the NW Atlantic. Mar Ecol Prog Ser 397:25-35. doi:10.3354/ meps 08318

Topsent E (1911) Sur une magnifique Geodia megastrella Carter du Muséum de La Rochelle. Archives du Musée de la Rochelle (Bulletin de la Société des Sciences Naturelles de la Rochelle):17, pl. 1

Topsent E (1928) Spongiaires de l'Atlantique et de la Méditerranée provenant des croisières du Prince Albert ler de Monaco. Résultats des campagnes scientifiques accomplies par le Prince Albert I Monaco 74:1-376, pls I-XI

Tucholke BE, Smoot NC (1990) Evidence for age and evolution of Corner seamounts and Great Meteor seamount chain from multibeam bathymetry. J Geophys Res-Sol Ea 95(B11):1755517569. doi: 10.1029/JB095iB11p17555

van Soest RWM, Boury-Esnault N, Hooper JNA, Rützler K, de Voogd NJ, Alvarez de Glasby B, Hajdu E, Pisera AB, Manconi R, Schoenberg C, Klautau M, Picton B, Kelly M, Vacelet J, Dohrmann M, Díaz M-C, Cárdenas P, Carballo JL (2017) World Porifera Database. http://www.marinespecies.org/porifera. Accessed February 2017

Watling L (2007) A review of the genus Iridogorgia (Octocorallia: Chrysogorgiidae) and its relatives, chiefly from the North Atlantic Ocean. J Mar Biol Assoc UK 87(2):393-402. doi:10.1017/ S002531540705535X

Watling L, France SC (2011) A new genus and species of bamboo coral (Octocorallia: Isididae: Keratoisidinae) from the New England seamounts. Bull Peabody Mus 52(2):209-220. doi:10.3374/014.052. 0202

Watling L, France SC, Pante E, Simpson A (2011) Biology of deep-water octocorals. Adv Mar Biol 60:41-22

Watling L, Guinotte J, Clark MR, Smith CR (2013) A proposed biogeography of the deep ocean floor. Prog Oceanogr 111:91-112

Zimmermann J, Hajibabaei M, Blackburn DC, Hanken J, Cantin E, Posfai J, Evans TC (2008) DNA damage in preserved specimens and tissue samples: a molecular assessment. Front Zool 5(1):1-13. doi:10.1186/1742-9994-5-18 